Buse Işıkhan

Gazi University, buseisikhan83@gmail.com, Ankara-Turkey

Aykut Sığın

Gazi University, aykutsgn@gmail.com, Ankara-Turkey

http://dx.doi.org/10.12739/NWSA.2016.11.3.3C0147

\title{
THE CONSTRUCTION OF CONSUMER CULTURE THROUGH CAR COMMERCIALS ABSTRACT
}

The aim of this study is to analyze the impact of commercials over consumption behavior. For this purpose, a qualitative content analysis was carried out on twelve car commercials aired on various television channels. The reason why car commercials were chosen specially is that this sector, which is an indispensable part of technology, advances at a remarkably fast pace and shapes consumption behavior in different manners. In this context, a reading of the commercials in terms of their social manipulations was carried out. The analysis of the commercials was handled through the views of such social theoreticians as Baudrillard, Veblen, Simmel, Featherstone, Fustier and Dichter on consumption. The fact that the consumption factor is foregrounded and the real object of consumption, which in this case is cars, is pushed into the background and then presented to the consumer necessitated a sociological investigation of shopping behaviors. At the end of the study, an analysis of consumption behavior will have been carried out and the effect of mass communication tools, which are crucial elements in the production and distribution of popular culture, will have been evaluated through commercial.

Keywords: Consumption, the Consumer Culture Theory, the Media, Car Commercials, Hedonism, Hyperreality

\section{ARABA REKLAMLARI ÜZERINDEN TÜKETIM KÜLTÜRÜNÜN İNŞASI}

Öz

$\mathrm{Bu}$ çalışmanın amacı reklamların tüketim olgusu üzerindeki kültürel ve ekonomik boyutlarının sosyolojik bir açıdan incelenmesidir. Bu amaçla, çeşitli televizyon kanallarında gösterilen on iki otomobil reklamı örneği üzerinden nitel bir içerik analizi yürütülmüştür. İnceleme için özellikle otomobil reklamlarının seçilmesinin nedeni, teknolojinin vazgeçilmez bir parçası olan bu sektörün son derece hızlı bir şekilde değişim göstererek tüketim alışkanlıklarını farklı şekillerde biçimlendirmesidir. Bu bağlamda, söz konusu reklamların toplumsal manipülasyonları açısından bir reklam okuması yapılmıştır. Söz konusu reklamların analizi Baudrillard, Veblen, Simmel, Featherstone, Fustier, Dichter, gibi sosyal teorisyenlerin tüketime yönelik görüşleri bağlamında ele alınmıştır. Reklamdaki tüketim unsurunun güçlendirilip asıl tüketim nesnesi olan arabaların daha arka planda tüketiciye sunulması alışveriş davranışının sosyolojik bir boyutta incelenmesini de zorunlu kılmıştır. Bu çalışmanın sonucunda özellikle popüler kültürün oluşmasında ve dağıtımında önemli bir faktör olan kitle iletişim araçlarının etkisine reklamlar üzerinden değinilerek tüketim davranışının analizi yapılmış olacaktır.

Anahtar Kelimeler: Tüketim, Tüketim Kültürü, Araba Reklamları, Hedonizm, Hipergerçeklik 


\section{INTRODUCTION}

Culture, in its simplest definition, is a concept related to the ways of living that all societies have. Despite that, however, it displays unique characteristics in each society. This peculiarity, while distinguishing societies from one another on the one hand, creates a kind of social structure constantly changing and transforming in its own way on the other. The said change and transformation process does not take place at the same speed in all the elements that fall under the umbrella term of culture.

The transformations in the material culture take place remarkably fast thanks to technological developments when compared to the transformations in the non-material culture. Showing technology as the mere cause of the transformations would be a reductionist approach, however. Accordingly, the impact of globalization and the resulting continuous flow of information, the socio-economic conditions of that society, the way its rural and urban are structured and many other factors need to be taken into account while evaluating the entirety of the cultural values of any given society.

culture, in any shape or form, is both reflected and constructed in the media, both traditional and new. An important part of the media and an essential tool in marketing, television advertisements play a key role in these processes. Consumer culture is no different than other kinds of culture both in that one needs to pay attention to as many factors in its analysis for a thorough understanding of how it is reflected in the everyday lives of people and that there is a reflexivity when it comes to using existing behavior patterns and constructing new ones.

The aim of this study is to analyze the impact of television advertisements over consumer behavior. For this purpose, the car commercials aired on various television channels were investigated. The reason why specifically car commercials and not others were chosen for this study is that the authors think that this sector, which is an indispensable part of technology - a tool for shaping cultures, advances at a remarkably fast pace and shapes consumption behavior in different manners. In this context, a reading of the commercials in terms of their social manipulations was carried out. The Consumer culture Theory notwithstanding, the study presents the theories involved together with the analysis of the car commercials with the aim of reinforcing the arguments discussed.

\section{RESEARCH SIGNIFICANCE}

Before analyzing the car commercials in terms of their significance in creating a consumer culture, it would be wise to understand what the Consumer culture Theory (henceforth, "CCT") is about, how it came into being and who its prominent proponents are.

The Consumer culture Theory investigates the consumption choices and behaviors of the actors on the market and while doing so, focuses on the social and cultural aspects of the phenomenon of consumption, rather than the psychological or economic ones, constructed, sustained and transformed via myths, narratives, ideologies and discourses (Joy and Li, 2012:142). An interdisciplinary field of study, CCT draws upon researchers from as wide areas as sociology, anthropology, media studies and feminist studies.

The consumer culture can, first and foremost, be associated with capitalism. Capitalism can be defined as "a system of wage-labor and commodity production for sale, exchange, and profit, rather than for the immediate need of the producers" (Scott and Marshall, 2009:59). Perhaps the most important term here, as far as the current study is 
involved, is "sale". The reason for this is that in a capitalist society, the producers of certain products, which were produced to be sold in the first place, feel the need to use certain manipulative marketing strategies on those who are to buy them (i.e. the "consumer") and this inevitably creates a kind of consumer culture.

There are differing ideas as to how the consumer society came to be. Figure 1 provides a list of the theses put forward by different theoreticians pondering the birth of consumer society.

Table 1. The theses on the birth of the consumer society

\begin{tabular}{|l|l|l|l|l|}
\hline Thesis (Author) & Historical Cause & $\begin{array}{l}\text { Social } \\
\text { Group }\end{array}$ & Century & Place \\
\hline Productionist & $\begin{array}{l}\text { Standardized } \\
\text { And Cheap } \\
\text { Goods }\end{array}$ & $\begin{array}{l}\text { Working } \\
\text { Class }\end{array}$ & XX & England \\
\hline $\begin{array}{l}\text { Antiproductionist } \\
\text { (McKendrick) }\end{array}$ & $\begin{array}{l}\text { Commercialization } \\
\text { System Status } \\
\text { Display }\end{array}$ & $\begin{array}{l}\text { Upper } \\
\text { Middle } \\
\text { Class }\end{array}$ & XVIII & England \\
\hline $\begin{array}{l}\text { Modernist } \\
\text { Campbel) }\end{array}$ & $\begin{array}{l}\text { Cultural } \\
\text { Consumption } \\
\text { Imaginative } \\
\text { Hedonism }\end{array}$ & $\begin{array}{l}\text { Middle } \\
\text { Class } \\
\text { Women }\end{array}$ & XVIII/XIX & England \\
\hline $\begin{array}{l}\text { Exchangist } \\
\text { (De Vries) }\end{array}$ & $\begin{array}{l}\text { Household } \\
\text { Organization } \\
\text { Monetary } \\
\text { Exchange }\end{array}$ & $\begin{array}{l}\text { Rural } \\
\text { Families }\end{array}$ & XVII/XVII & Holland \\
\hline
\end{tabular}

Source: Sassatelli, 2007:15.

Sassatelli (2007:15-20) manages to make an in-depth discussion of the different ideas regarding how the consumer culture came to be. According to him, considering the study on the increase in consumption at the time, researchers such as Jan De Vries (1975), Neil McKendrick (1982) and Colin Campbell (1987) shifted the paradigm from a "productionist" view of the consumer society, which holds that the consumer society came into being as an inevitable result of massproduction, into an "anti-productionist" one, which maintains that it was the demand for goods, more than their production, that transformed the process of modernity. The latter perspective changed the focus of the studies from a purely economic window into one that is highly influenced by social and cultural factors.

First of all, McKendrick, who believes the new ways of consumption arose in the second half of the 18th century in England, puts forward a "consumerist" basis for the birth of the consumer society, contending that industrialization is not the cause of the consumer society, but rather its effect. Instead, the commercialization process and the want to show status, in line with the lifestyle of the bourgeoisie of the time, are seen as the catalyzers of the consumer society.

For Campbell, on the other hand, conspicuous consumption is a desire for novelty - thus "modernist"- in one's life. The new consumer is a kind of "imaginative hedonist" who mentally attaches their desires to objects and lets them loose once they obtain the objects in question. Campbell believes that the consumer revolution occurred in the period between the end of the 18th century and the beginning of the 19th century mainly through middle-class women who were constantly "daydreaming" about objects of desire. 
Focusing on Holland from the end of the 17th century onwards, De Vries regards the (rural) family as the primary unit in causing the consumer revolution. De Vries purports that, even though at the time income rates decreased, spending increased and this was done mainly through the financing of expenditures in the family: People worked more to produce for the market and this, in return, provided them with money to be used in consumption. In other words, consumers were also producers and they were exchanging productive resources within the family.

Apart from these researchers, the American economist and sociologist Thorstein Veblen also contributed to CCT, mainly through his "Theory of the Leisure Class". In his work, Veblen writes on American capitalism and its dominant class: the "leisure class". The leisure class is one of waste and idleness and it indulges in "conspicuous consumption" (Abercrombie, Hill and Turner, 1994:468), which can be defined as the act of purchasing "goods and services not for their obvious utility but for show: to demonstrate that they could afford such things" (Bruce and Yearley, 2006:47-48).

Another theoretician that touched upon the issue of consumption was the French sociologist Pierre Bourdieu, who claimed that "tastes" are not innate, but rather socially conditioned. In a sense, consumer choice and the chosen objects signify a "symbolic hierarchy" created by the socially dominant, which forms dichotomies of "high" versus "low", "sacred" versus "profane", "legitimate" versus "illegitimate" etc. In this respect, for Bourdieu, taste is a "social weapon" of distinguishing and distinction (Allen and Anderson, 1994:70).

For yet another French sociologist, Jean Baudrillard, consumer culture is linked to his concept of "hyperreal", which is the idea that what is real is no longer accessible. For instance, the 1991 Gulf War was not real, but hyperreal in that it was meaningful to those not directly involved in the war only insofar as they saw the televised coverage of the war (Bruce and Yearley, 2006:17). The meaning and the details of the war disappeared or became ambiguous to audiences as soon as the television was turned off.

Besides, consumer culture is closely related to a fashion system. With capitalism, objects are turned into commodities and as a result, qualitative variations become quantitative variations quantifiable via money. Messages also go through this process, whereby meaningful differences between messages become a fashion message instead. The act of preference comes down to fashion more than identity. For instance, preferring local foods does not imply that the person comes from that particular local community, but rather, their wish to express their liking of the local foods in question (Ritzer and Goodman, 2006:164).

It is safe to contend that, as tools of mass communication developed and became an indispensable part of daily life, they inevitably had an impact on people's ways of living and the formation of consumer patterns via television shows, commercials, competitions and the like (Çınar and Çubukçu, 2009:296). As such, commercials are of great significance to sociological studies as social determinants. Statistically speaking, Taşyürek (2010) found out that \%81.5 of the consumers in her fieldwork bought a product or service which they did not consider buying before upon seeing the commercial promoting them.

Furthermore, car commercials are usually seen as good examples for the type of advertising that construct a type of consumer culture. The importance of this study lies in the fact that these kinds of commercials need to be analyzed from a sociological point of view with 


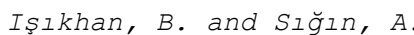
Social Sciences (NWSASOS), 3C0147, 2016; 11(3): 226-242.

the purpose of finding out how they guide marketing and buying behaviors.

\section{ADVERTISING AND THE ANALYSIS OF CONSUMER CULTURE OVER CAR COMMERCIALS}

Advertising is one of the most powerful tools of the mass media and it usually attempts to make the biggest impact in as short a time as possible. Authors such as sondape and Frybyiarper accept the time period around 3000 B.C.E as the beginning of advertising. The signboards merchants put in front of their stores with the aim influencing people and marketing their products are regarded as the first examples of advertising. However, 30 years after the invention of the printing press in 1450, an English typographer faces the problem of marketing the books he publishes and decides to print bulletins publicizing them. These bulletins reproduced to hand out in churches during the religious ceremonies comprise the first printed media examples in the history of advertising (Topçuoğlu, 1996:181$186)$.

As for Turkey, "İlancllık Kollektif Şirketi" (ílancılık Collective Company), founded by the Cairo Unit Head of Agence FrancePresse E. Hoeffer along with two other businessmen in 1909 can be considered the first international ad agency. Television enjoyed an advertising tool status beginning from 1972, which happens to be the year when advertising was developing and becoming prevalent at a fast pace. $80 \mathrm{~s}$ are regarded as the turning point for advertising activities. The fact that color transmission launched in 1983 meant that important developments for advertisers and for advertising quality in general were on the horizon (Topçuoğlu, 1996:181-186).

The main purpose of an advertisement is to develop a behavior of purchasing the advertised product in the consumer. The fact that the consumer might not need the product from a functional point of view yet still want to buy it is carried out via various ways of meaning transfer.

Baudrillard believes that the effects of the tools of contemporary mass media are way different and far deeper than any other technology. The emergence of the mass media transformed the nature of our lives. Television not only presents the world to us, it also defines "what" the world we live in is. There is no "reality" which television allows us to see. Reality is in fact the sequences of images that describe the messages (or rather, the phenomena) as a global event in television screens. This is, as mentioned before, what Baudrillard calls "hyperreality". Baudrillard claims that in a world of mass media, the behaviors of people and the mass media images are mixed up and thus emerges a new reality - a hyperreality. The world of hyperreality consists of images which get their meaning from other images and so, they are baseless in the "external reality" (Giddens, 2000:403).

In her work, McRobbie (1999:33) underlines that the images displayed in the media permeates all areas of people's lives. So much so that these images are with them even when they go about their ordinary lives or worry about making two ends meet.

For Zorlu (2006b:25), consumer goods and the consumer culture is either legitimized or shunned with references made to the traditional or local. People's lifestyles, their historical and social fabrics, are their ways of constructing symbolic borders in the context of consumption patterns and cultures.

When the modern society is taken into consideration, the message clothing gives out is that it includes vanity and competition in 
itself in line with the themes of novelty, difference, belonging and indecisiveness. In this way, the fashion of the modern provides masses with consumer goods over contrasting themes. According to Simmel, fashion has two functions: merging and dividing. While generalization, continuity, social equality and similarity are merging elements, privatization, change, extraordinariness, creativity and personal differences are dividing factors. The images fashion creates in terms of consumption can be arranged by referring to as many symbolic areas as identity, class, status and sexuality in a contrasting way. For instance, torn, faded jeans associated with poverty can be worn by the youth belonging to the upper class (Zorlu, 2006b:207-210).

In this respect, especially visual stimuli that trigger the target audience's emotions, desires and imagination are used. A type of means for having such an impact is indeed language, together with signs and symbols. Effective slogans are used in advertisements in order to form a consumer perception towards the product in question and to construct consumer behavior in the desired manner. Ford Focus, for example, is released to the market with commercial slogans that go "Beklentinizi yükseltin" ("Expect more") and "Yaratıcılık elinizde" ("You are creative").

Another strategy used in the commercials to attract the attention of the consumer is to transmit messages which say that daily lives are being aestheticized. According to Featherstone, the consumer culture caused a new kind of perception of situations. Lifestyles' aestheticization led objects of need to get new symbolic meanings. Featherstone explains the consumption of cultural goods and practices in relation to post-modernism. Changes in the cultural field as regards the production, circulation and spreading of symbolic goods are observed in post-modernism. These can be summed up under two headings. The first one is the growing of the consumer culture and the emergence of a sector that constantly attempts to keep this culture alive. The second transformation is the aestheticization and stylization of the consumer culture. Turning life into a piece of art is realized through the rapid flow of the signs and images that fill in the consumer culture. Advertisements affirming that lifestyles should be transformed are the most effective means of communication in doing just that (Zorlu, 2006a:266-270).

Actually, the transformation of one's lifestyle inherently has the connotation of their having control over their life. This image is given implicitly and in association with the product in certain advertisements. If the person has that product, he or she will have the means to bend the conditions and even the "visuals" of his or her life. Furthermore, the same person also gains the power to dominate nature itself by being able to transform and change it. The important attribution here is to be able to dominate and subordinate. By purchasing the said product, the consumer manages to establish a kind of dominance over his or her life and surroundings.

The Dacia Duster SUV 4x4 commercial gives the audience a perfect example of this. In it, the Dacia Duster SUV $4 \times 4$ driver leaves the city and comes across a building when he detours. At this point in the commercial, the driver uses a device, which is the car's remote control, and gets rid of the building. The location where the driver is at suddenly turns into a forest, or rather, a place suited to his wanting. As much as this is nothing more than a fantasy in real life, a sensation of having that kind of power by owning that vehicle is aroused within the audience. Besides, the SUV, suitable for both rural and urban driving, is shown as being able to be driven against the poor conditions presented by either. The driver has the liberty to 


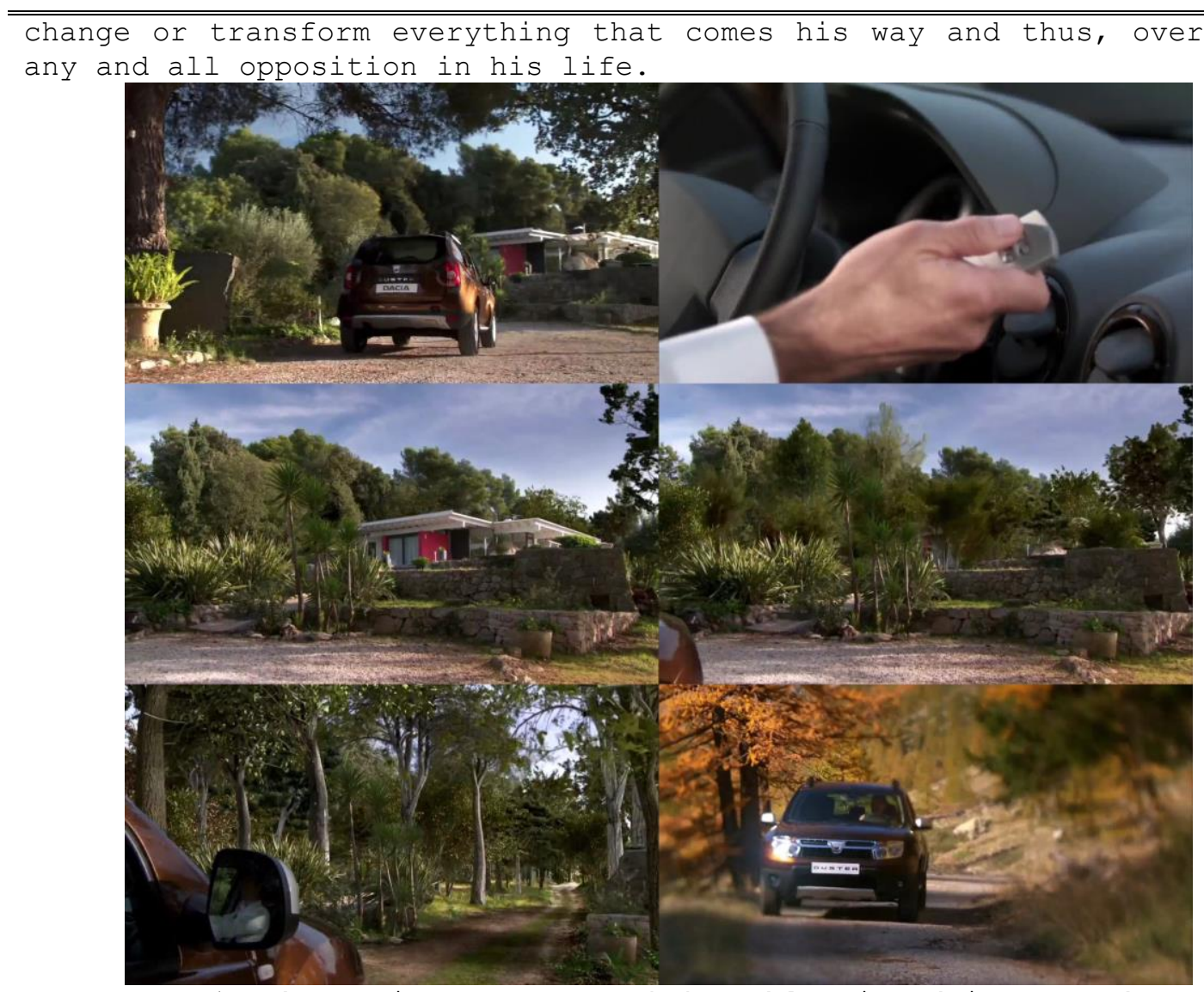

Image 1. The Dacia Duster SUV $4 \times 4$ enables its driver to change external conditions, giving him authority over nature

The BMW X1 commercial launches with the "X bir yere git" ("Go to an x place"), "X bir filmin içindeymiş gibi, x bir şehre yolun düşmüş gibi git" ("Go as if you're in an $x$ movie, go as if you came by an $x$ city") slogan. First, there is a mountainous and then an urban scene. The destination, however, is not important. Wherever the car passes through, fluctuates. Driving this car would give the consumer a sensation of dominance over nature. Everything fluctuates, yet the BMW $\mathrm{X} 1$ stands firm. In fact, it is the BMW Xlthat causes the fluctuations. This promotes a sensation of self and individualism, as well.

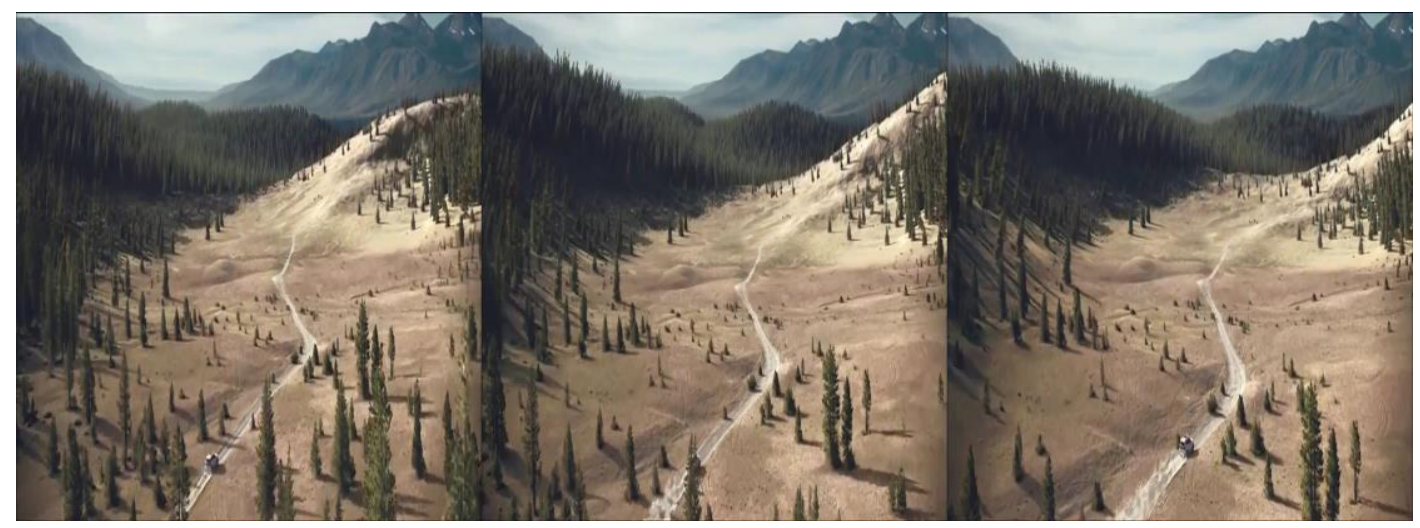

Image 2. The landscape towards the end of the pathway fluctuates in accordance with the BMW $\mathrm{XI}^{\prime}$ s movement, giving off a sense of domination over nature 
In yet another example, the Mercedes-Benz commercial, a driver drives on a desolate land on his own when suddenly the Grim Reaper appears sitting at the passenger seat and grinning, says "Sorry" to the driver. Shocked, the driver turns his face on to the road and sees a truck. He manages to stop at the last possible second and turns his face back to the Grim Reaper and says "Sorry". The theme of death shown and it is simulated that it can be cheated. The car grants immortality to whomever buys it - the owner of the car dominates over death.

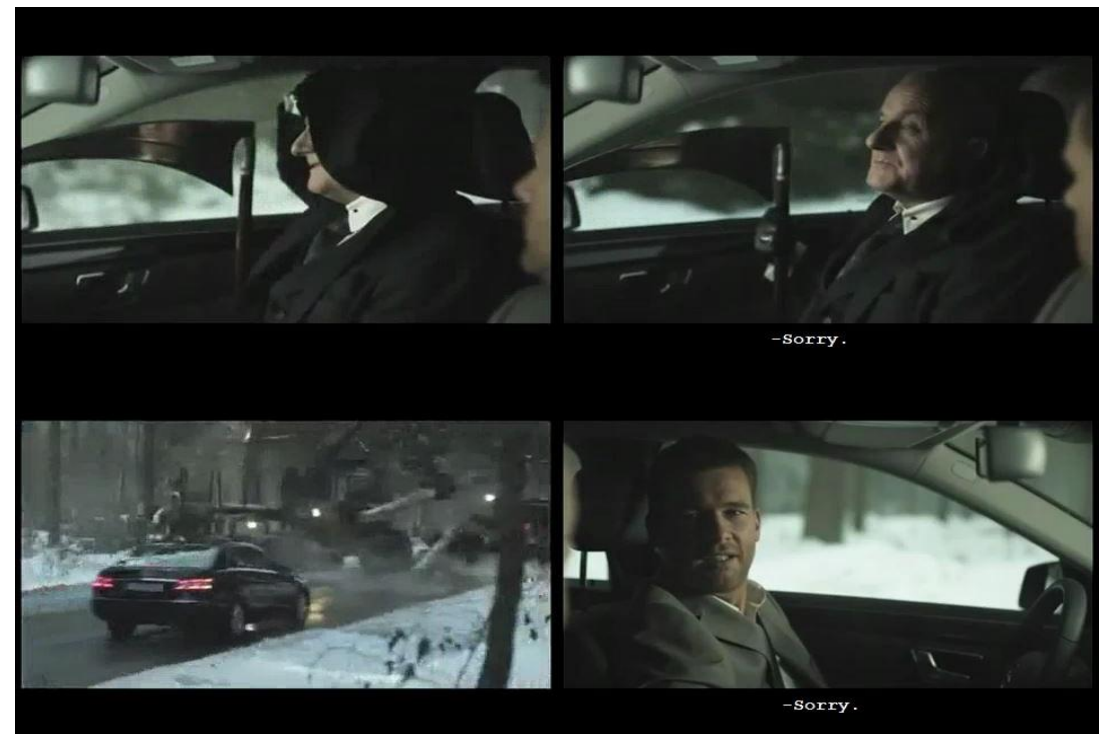

Image 3. The Grim Reaper fails to take the Mercedes-Benz owner's life thanks to the car's braking system

In the commercials, the audience is led to see more than just the consumer good by way of introducing other factors and persuasion towards consumption is formed accordingly. By means of presenting the product through a different lens of reality, the other conditions (dominance over conditions, nature and life) promised by it are also demonstrated to become a reality if the consumer owns the product.

The consumer believes himself or herself to be a member of the imaginary world or social class created in the commercial by buying the commercialized product. For example, they will have bought the world and even the personality traits they think they cannot have by way of buying the commercialized product. The meanings attached to objects or the sub-meanings related to the product described by the language in a given advertisement might arouse the desire to buy the advertised goods. In many car commercials, for instance, it is emphasized that the consumer will be more respectable and/or prestigious by purchasing that car.

The Renault Clio commercial is a good example of this. In it, a male motorcycle rider is shown as being kept at arm's length by others. If regarded through the scope of a functionalist approach, solely the car's technical properties would be expected to be described. In this commercial, however, a feeling (of exclusion) is foregrounded even to the point of surpassing the car: The man is ignored because he does not own a Renault clio. Technically, though, this man is en route and is riding to his destination. On the other hand, the commercial makes the audience feel that this on its own is not enough, since women do not see the man on the motorcycle and focus on the clio driver right next to him. There is only one solution to this problem and that is to buy the car in the commercial. As can be 
seen, what is bought here is not the car, but the respect and prestige it gives its owner. The commercial turns the act of buying into one of prestige, privilege, respect and identity formation.

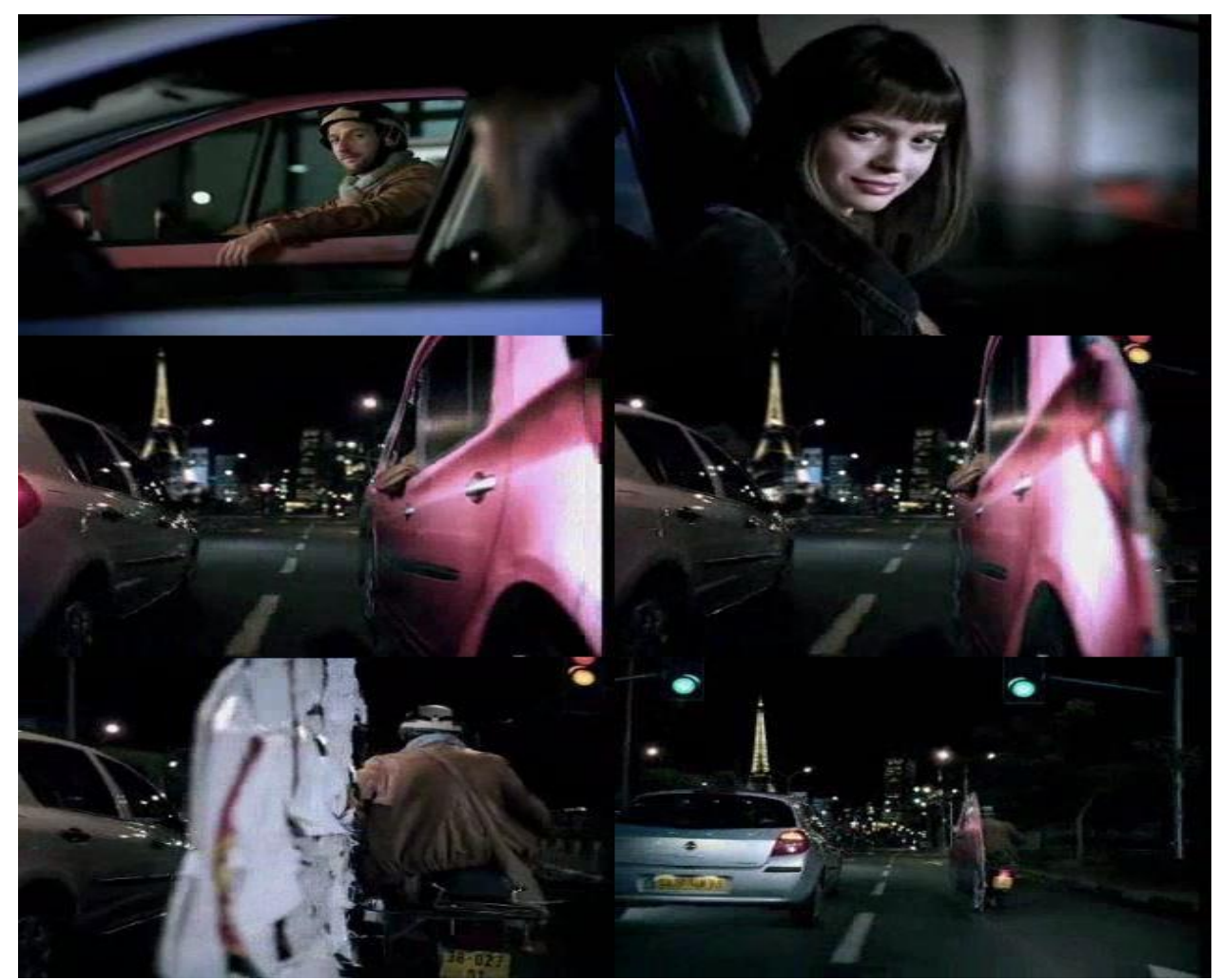

Image 4. A man ignored because he does not own a Renault clio receives the attention he seeks by finally obtaining a (fake) Renault Clio

Fustier (1974:24-32) deals with this issue in a different manner. The need to love objects is obvious in emotionally unstable people in particular. People with unsatisfying work conditions are also vulnerable. When a person's emotions and feelings are addressed through visual and linguistic stimuli, he or she is affected. If the contents of the stimuli are also suitable with the characteristics of the audience, the impact is further augmented.

The concept of "need" is reproduced in CCT. Need is no longer used strictly in the sense that they must be met, but rather, they should address the sensation of pleasure. In this context, hedonism is explicitly emphasized. Goods which will cause pleasure only because the consumer owns them are provided (Arslan, 1999:115-117). The "I just want it to be mine" message relayed in many car commercials is an example for this. People use the term "enjoy" not to refer to a product's material value, but to emphasize the feeling of joy that it creates.

In the Renault Mégane sport Tourer commercial, the seller asks questions as to why the consumer might be interested in buying that car. The consumer rejects all the possible reasons for buying the car and replies in a tone of "I just want it". The commercial is a clear example of directing the audience to buy the car by instigating a sense of hedonism. It is now a rationalized idea that a sense of wanting based on hedonism is indeed a viable need. 


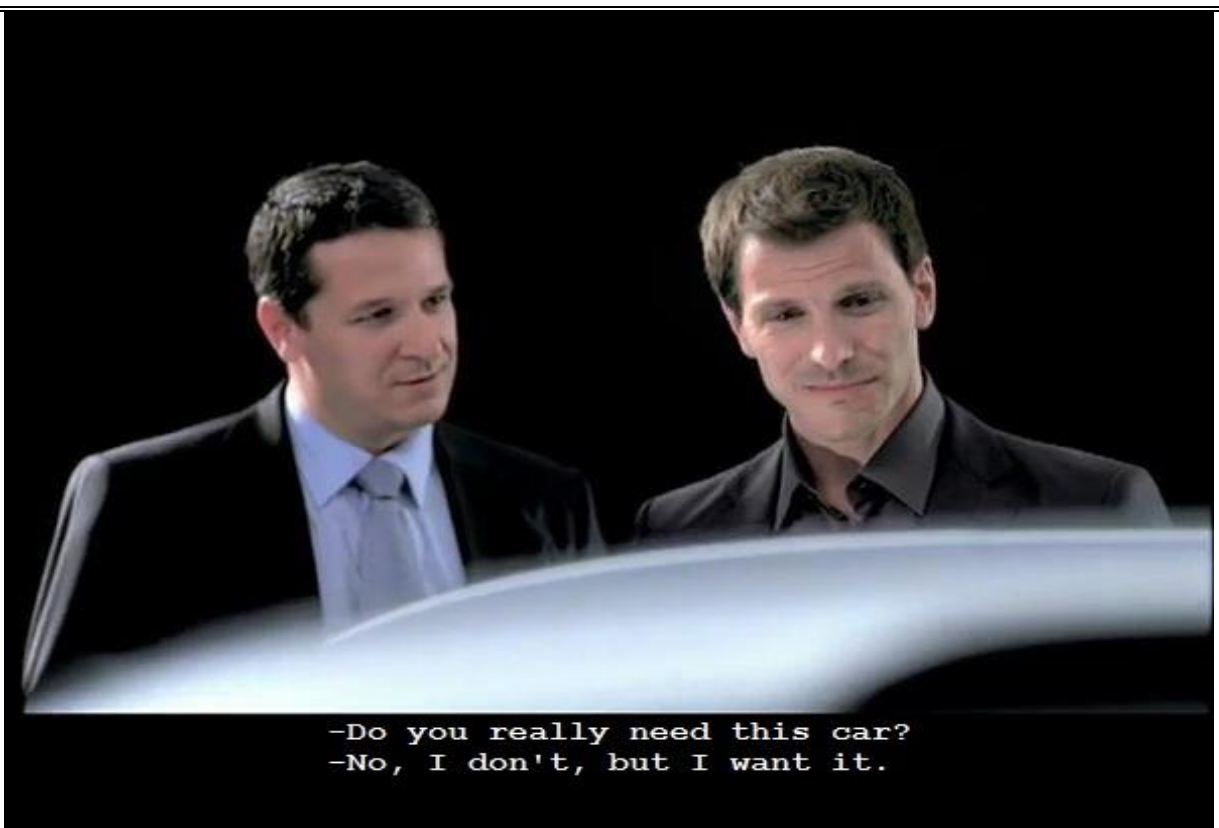

Image 5. The seller makes a list of the reasons why the buyer might want to buy the Renault Mégane Sport Tourer, all of which the buyer rejects and says he simply wants it

In another example, a KIA Optima is being carjacked by someone resembling a policeman, who is then knocked off the car by someone in a chopper. The pilot of the chopper, who now has possession of the car, loses control of it when Poseidon, God of the sea in the Greek mythology, seizes it. However, aliens take possession of the car in the course of the commercial. At the end of the tussle, the car ends up in the hands of an ancient people, who greet it as if it were a God. As can be understood, the optima is an object of desire for whose possession living beings of different ages, cultures, statuses and even planets compete. The only thing in common among all these differences is that they all want the car for themselves and not share it with anyone else. In this context, a sense of individualism and hedonism is promoted.

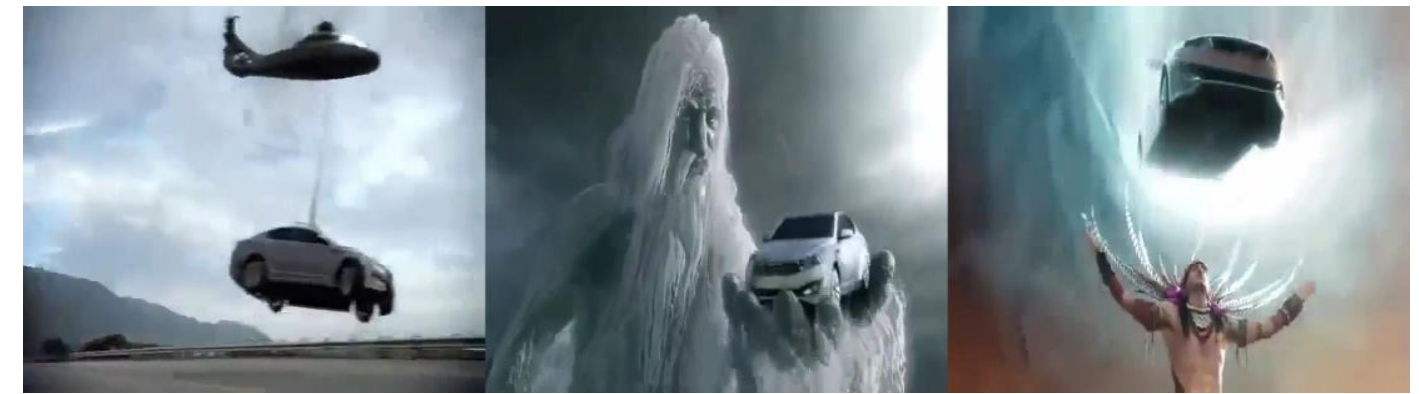

Image 6. The KIA Optima is constantly attempted to be taken possession of by various beings, bolstering the idea that owning the car will make one happy, whoever they might be

Yet another commercial where the self and the desire to own are foregrounded is the Toyota RAV4 one. In this commercial, individualism is emphasized over the concept of family, which is a collective unit. A married couple rush to take the Toyota to work that morning. Both the husband and the wife set up fatal traps to eliminate the other. Perhaps the most important aspect of the commercial is that both 
parties enjoy what they are doing and deeply want to "win". A hedonistic approach is at play here. Consumer patterns ready to get rid of the family concept due to self-desires are presented. It is interesting to note here that a parallelism could be drawn between the birth of the consumer culture and what this commercial hints at: "The producer society achieved its goals through collective action, whereas consumption is achieved in isolation" (McDonald and Wearing, 2013:85). In the case of the Toyota RAV4 commercial, the family achieved its goals through collective action, but the act of consumption is to be done on one's own.

There exist obvious signs of, in Veblen's words, "conspicuous consumption" in car commercials. Expressions such as "If you buy this product, you will be distinguished, your prestige will rise and you will become the person you want to be" are now a common part of these commercials. All cars carry the passenger to where they want to go, yet this is not sufficient. Accordingly, rather than the commercial function and properties of the car, the main factor that makes a car desirable now is the feeling of freedom, prestige and creativity that it comes with.

In the Renault Fluence commercial, a father taking his daughter to school in the morning is narrated. Once the car is in front of the school, the girl pretends that she cannot open the door and asks for her father to do it for her. Upon getting off the car, she acts in such a way that her friends think the car is her private car and her father is actually her driver. She heads towards the school building, with admiration and jealousy on the faces of her friends.

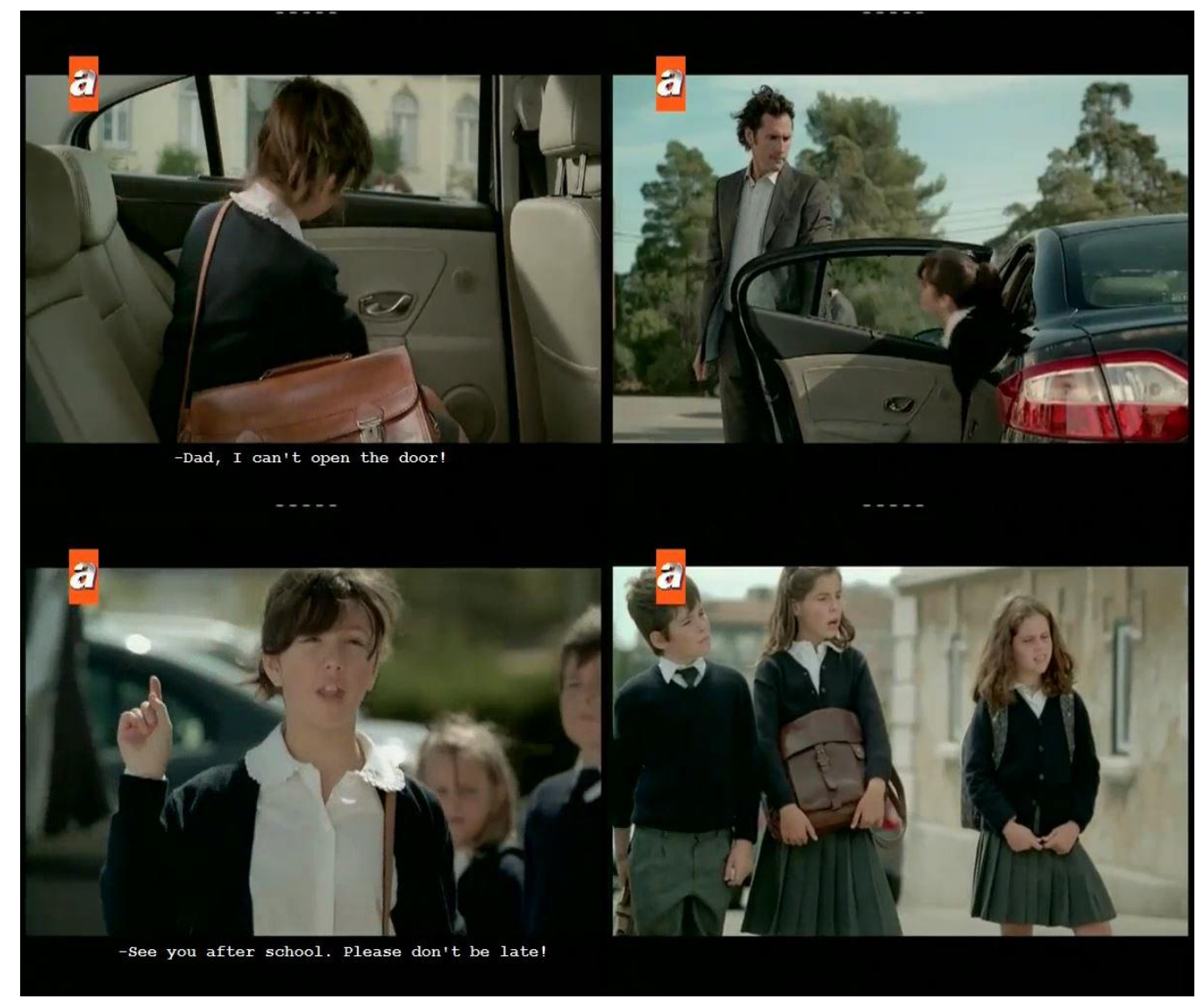

Image 7. The girl has her father open the door for her and then pretends that her father is actually her driver 
According to Veblen, there are two features that make a product conspicuous: that it has relative expensiveness and it triggers admiration in others. The reason why a person buys the more expensive and attractive one of two products that essentially have the same properties is that the consumer aims at conspicuous consumption (Zorlu, 2006a:163-172).

Veblen (2014:130-132) touched upon the topic of the clothes which we choose and buy in the modern society and how they are more than just means of covering our bodies - they actually "mean" something. Getting dressed to give a message even took place of getting dressed in accordance with the season. He considers the case of some people wearing clothes even though they are not suitable for the winter from the perspective of fashion, rather than season.

In the Wolkswagen Jetta commercial, presented with the slogan "Herkes bu prestije sahip olmak ister" ("Everyone wants to own this prestige"), a businessman about to get on a car waiting at the airport to pick him up sees the Wolkswagen Jetta, which is there to pick up somebody else, probably a person from the Far East. The businessman walks up to person next to the Jetta and, with hopes of getting on the Jetta, starts acting like the person from the Far East whose name is written on a piece of paper. The driver does not believe that that is the person he has been waiting for due to his looks, but the businessman still manages to get on the car. The businessman acts like someone else in order to have the prestige the car provides.

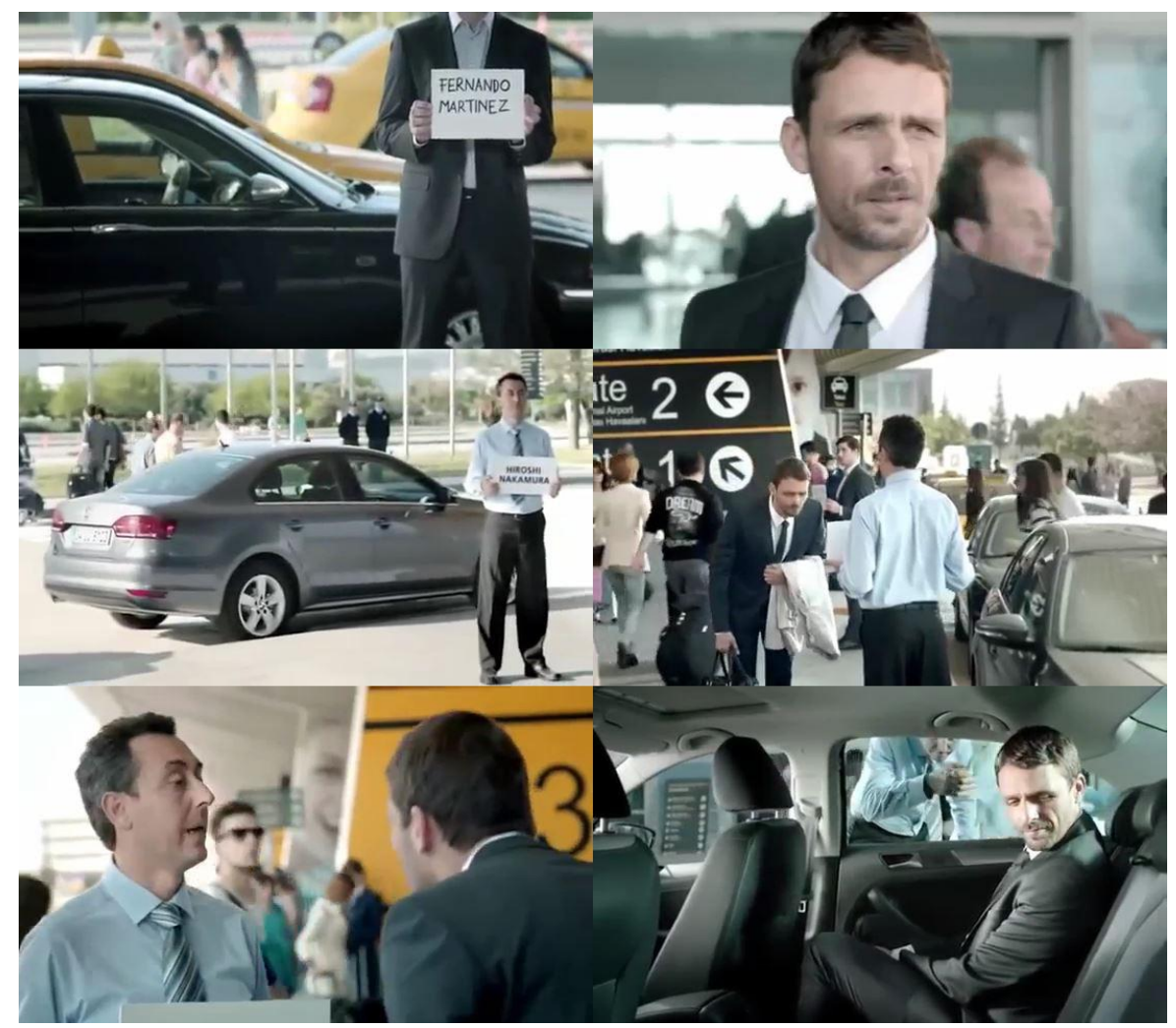

Image 8. Fernando Martinez, more interested in the car waiting to pick Hiroshi Nakamura than the one waiting for him, pretends to be Hiroshi Nakamura in order to get the prestige that the car provides.

Another car commercial that is in comply with Veblen's theories is the Renault Clio (Cranberries - Zombie) one. In the commercial, the story of two Clio drivers, one young, one old, is told. They stop next 
to one another at a red light. The young driver, while singing the song he is listening to out loud, makes faces at the other, old driver. The young driver is actually on his way to her lover's place. When he arrives at his destination, he realizes that the old driver he met on the road is actually the father of her lover's. Both being surprised, the father says "En azından araban güzelmiş" ("At least your car is beautiful"). The message is: By having the product, we can get away with any hardships. The car is of high quality and this gives the owner certain privileges.

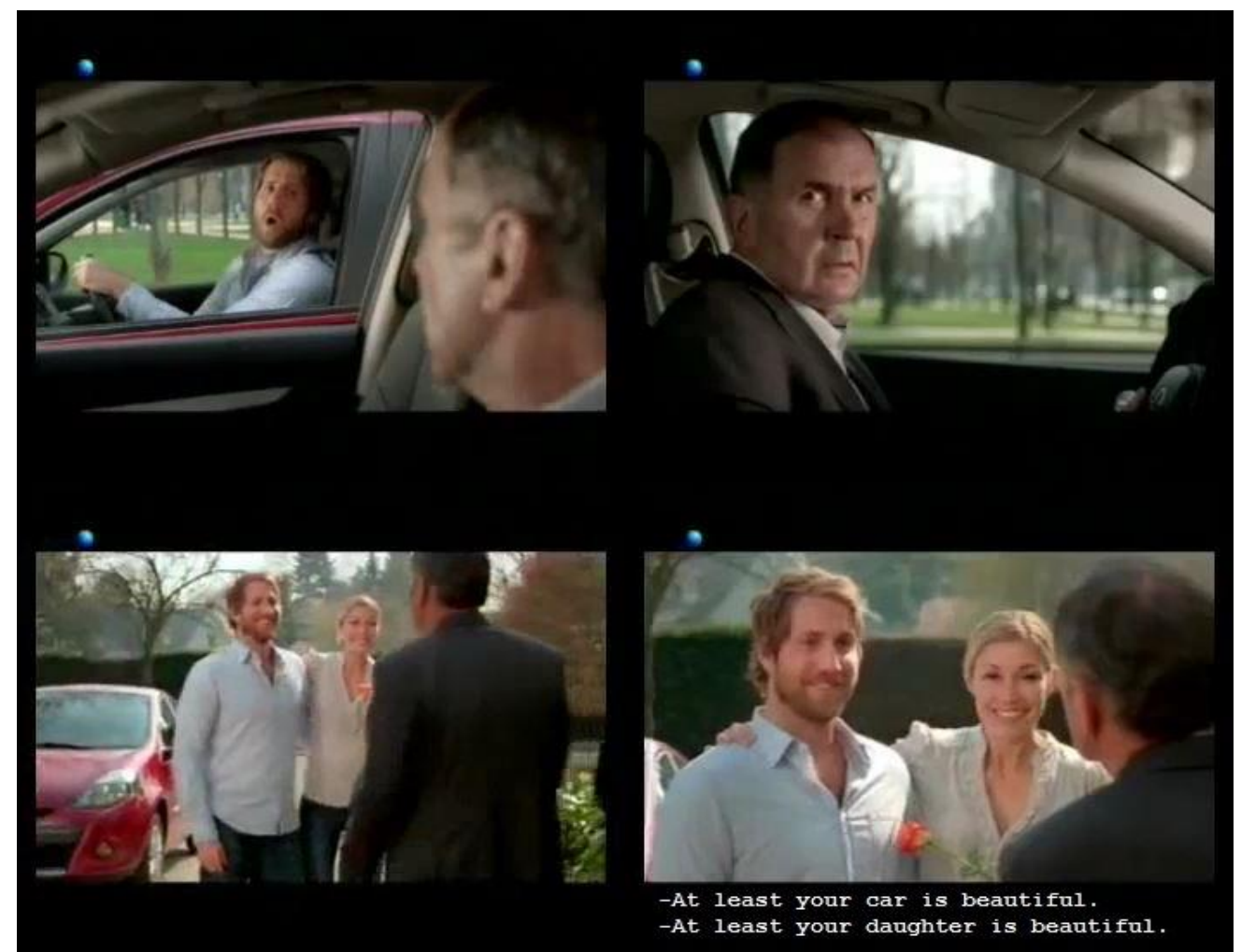

Image 9. The misbehaving youngster turns out to be the lover of the man's daughter. He gets away with his mannerisms thanks to his Renault clio.

In his article "The Metropolis and Mental Life", where he investigates Berlin at the end of the 19th century, Simmel puts forth that the problems the individual faces in the modern era are due to the battles they fight in order to preserve their autonomy in the growing urban life. Simmel speaks of an individual that tries to protect their individuality in the face of social powers that want to usurp them. From the end of the 19th century onwards, the puritan individual Weber mentions has disappeared and the urban life has become a field of consumption in which individual preferences can be displayed. For this reason, whoever the individual wishes to be perceived as in the city, he or she consumes that way. On the other hand, the style the individual uses to differentiate himself or herself from others should also be used by others. In this way, the individual can differentiate himself or herself from others as long as he or she shares the cultural symbols with others (Aydoğan, 2009:204).

In line with this view, for Zorlu (2006b:201-202), it is aimed in advertisements that popular symbols which can be commercialized are objectified. Also, instead of presenting "what is", commercials intend 
to show the consumer the "ideal". The way nature is demonstrated also serves a commercial purpose.

In other words, it is no longer what the objects are, it is their images that matter. Dichter defines this as "brand image". Consumers are stimulated to buy the product or service at issue with promises that they will have such images. The consumer believes that they are completely free in their choices, thinking that they act in accordance with their conscious. The suggestions made through advertisements, however, are very strong motivators. All consumers, whether intentionally or unintentionally, want to show a product that they bought (Fustier, 1974:24-32).

The strategy of implicit persuasion which advertising agencies employ in the formation of consumption behaviors, come up with different fictitious worlds. The sense of power, the feeling of immortality, the fantasy of dominating over and directing everything all reflect reality in different forms (Fustier, 1974:24-32).

"Hiding" and "simulating" are two of Baudrillard's crucial concepts. A hyperreality is formed through the images which denote a fake sense of having or not having something in the media. Instead of realities, people are addressed through their replicas or simulacra. As a result, the feelings, reactions and attitudes displayed in mass communication tools, which are key in the creation of the said simulacra, get mingled with the genuine feelings, reactions and attitudes of people (Bal, 2004:133-135).

In the Honda CRV 1.6 i-DTEC commercial, illusory images were used. Locations or objects that appear to be 3D at first sight become images as the Honda CRV 1.6 i-DTEC comes in. The only reality in the commercial video is the Honda CRV 1.6 i-DTEC and everything else is nothing more than an illusion.

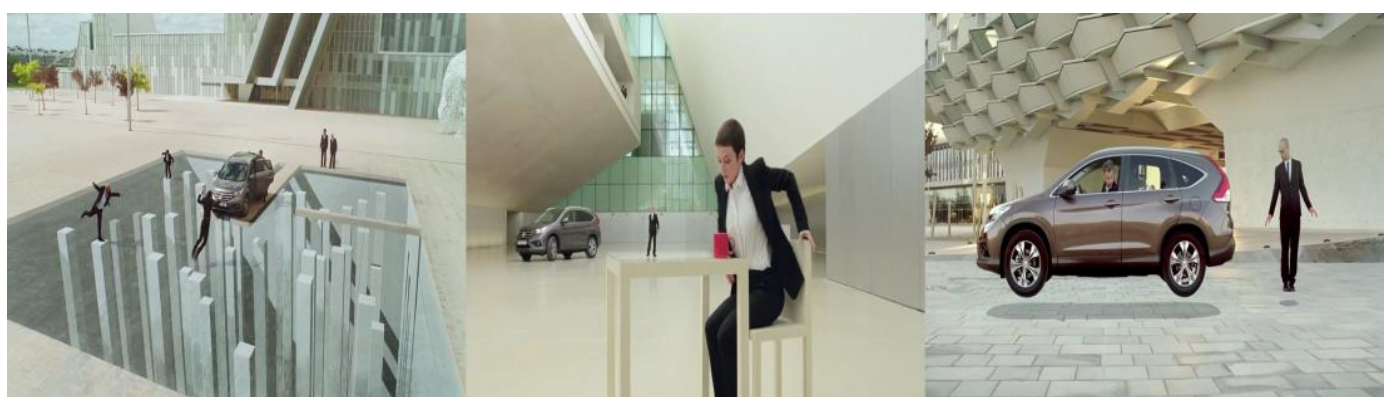

Image 10. Everything is illusory in the world of Honda CRV 1.6 i-DTEC but the car itself.

In the Wolkswagen Golf commercial, while the car is being visually demonstrated, the utterance "Dünyayı saniyenin onda biri hızıyla algılayabilen, sıfır desibel şiddetindeki sesleri duyabilenler için, yani kısaca herkes için Golf" ("Golf for those who can perceive the world in one tenth of a second and hear sounds in zero decibels, namely, for everyone") is pronounced. Here, the sense of reality is distorted by describing a target audience never to be. Hence, a hyperreal situation is presented. The purchase of the product is also attempted to be rationalized by means of addressing the consumer in such a way that they feel "they are that way and only a vehicle of that caliber can be appropriate for them". Also, it is implied that in comparison with what the product will get the consumer, its price is nothing to be concerned about. In this way, the consumer does not have to deal with the material aspect of the product - another important part of CCT. 
Baudrillard (2010:153-155) refers to McLuhan's "a tool is a message" approach in his theory, meaning such mass communication tools such as television and radio by "tool". What is presented to the consumer through mass communication tools is not the reality of what is actually happening, but the perception of the reality established by these tools themselves. However, this message of reality, besides distorting the reality of what is happening, also has a high commanding influence on the consumer. The consumer consumes not the actual product, but the message constructed using a series of signs over that product. As a consequence, it is possible to speak of the commodification of the message in question. The consumer is led to think in different ways and indirectly motivated to consume. In short, Baudrillard's simulation can be easily spotted in television advertisements, because the consumer no longer deals with objects, but with the ideas about the objects. What matters is not "what" the object is, but "how" they are presented.

The Renault Clio sport 197 commercial also supports Baudrillard's theory of simulacra. The Renault Clio sport 197 goes so fast that it can catch and even surpass a speeding bullet. The consumer, provided he or she buys the car in the commercial, can reach up to that speed, which is impossible in reality. Perception of reality is again distorted by means of displaying a car that opens the door to a world of hyperreality.

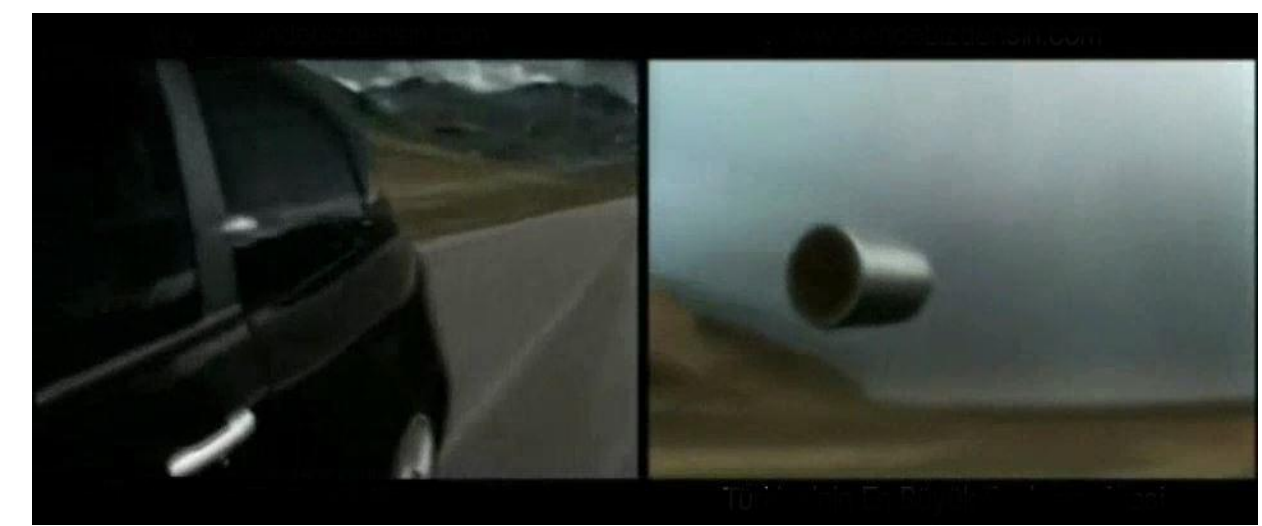

Image 11. The Renault Clio sport 197 is so fast that it races a speeding bullet, a clear example of hyperreality

\section{RESULTS AND DISCUSSION}

The purpose of this study was to analyze car commercials with reference to their sociological implications. To this end, car commercials aired on television channels were first watched and then twelve of them were chosen with respect to 4 themes which were deemed to be common in the previously seen commercials: 1hedonism/individualism, 2-hyperreality, 3-social status/prestige and 4-dominance (over nature and conditions). The consumption behavior in car commercials, it turns out after a qualitative content analysis, is constructed over these four concepts.

At the end of the study, it became clear that three of the commercials, the Renault Mégane, ToyotaRAV4 and KIA Optima ones, appealed to hedonistic and individualistic senses. Three of the commercials, the Wolkswagen Golf, Honda CR-V and Renault Mégane Hatchback ones, fell into the hyperreality category. Three of the commercials, the Renault Clio, Renault Fluence and Wolkswagen Jetta ones, focused on the concepts of social status and prestige. Lastly, three commercials, the Mercedes-Benz, Dacia Duster SUV 4x4 and BMW X1 
ones, touched upon the theme of dominance over nature and conditions of life. As a result, it is safe to say that, from a social constructivist point of view, car commercials construct a consumer culture based on these four concepts.

Commercials and popular culture, over which social continuity is established, always manage to find a product to commodificate. And it does so by transforming and reproducing the behaviors of the consuming masses. Commercials also serve the purpose of legitimization of material or non-material factors of culture. However, when considered from a wider perspective, a product commodified over time may start to become a cultural element in a given society. In this such a case, a transformation and change in cultural elements is seen.

In addition to the goods popular culture provides, patterns of behavior and attitudes are also produced. The produced behavior and attitudes become a part of the cultural change by means of systematization. These products of popular culture, which take the place of the old, reconstruct themselves after a process of consumer culture is "established" again and again.

\section{REFERENCES}

- Abercrombie, N., Hill, S., and Turner, B.S., (1994). The Penguin Dictionary of Sociology. Middlesex, England: Penguin Books Ltd.

- Allen, D.E. and Anderson, P.F., (1994). Consumption and Social Stratification: Bourdieu's Distinction. Advances in Consumer Research, 21, 70-74.

- Arslan, A., (1999). Felsefeye Giriş. Fourth Edition. Ankara: Vadi Yayınları.

- Aydoğan, F., (2009). Tüketim Kültürünün Gölgesinde Kentler. Marmara Üniversitesi İ.̇̇.B.F. Dergisi, XXVII, (2), 203-215.

- Bal, H., (2004). İletişim Sosyolojisi. Isparta: Süleyman Demirel Üniversitesi Yayınları.

- Baudrillard, J., (2010). Tüketim Toplumu. Fourth Edition. İstanbul: Ayrıntı Yayınları.

- Bruce, S. and Yearley, S., (2006). The Sage Dictionary of Sociology. Wiltshire, Great Britain: The Cromwell Press.

- Campbell, C., (1987). The Romantic Ethic and the Spirit of Modern Consumerism. Oxford: Basil Blackwell University Press.

- Çınar, R. and Çubukçu, İ., (2009). Tüketim Toplumunun Şekillenmesi ve Tüketici Davranışları -Karşılaştırmalı Bir Uygulama-. Atatürk Üniversitesi Sosyal Bilimler Enstitüsü Dergisi, 13 (1), 277-300.

- De Vries, J., (1975). 'Peasant Demand Patterns and Economic Development: Friesland, 1550-1750', in W.N. Parker and E.L. Jones (eds). European Peasants and their Markets: Essays in Agrarian Economic History. Princeton: Princeton University Press.

- Fustier, M., (1974). Tüketim Psikolojisi. S. Gürbaşkan (Trans). İstanbul: Reklam Yayınları.

- Giddens, A., (2000). Sosyoloji. Ankara: Ayraç Yayınları.

- Joy, A. and Li, E., (2012). Studying Consumption Behaviour through Multiple Lenses: An Overview of Consumer Culture Theory. Journal of Business Anthropology, 1 (1), 141-173.

- McDonald, M. and Wearing, S., (2013). Social Psychology and Theories of Consumer Culture: A Political Economy Perspective. New York: Routledge. 
- McKendrick, N., (1982). 'Commercialization and the Economy', in N. McKendrick, J. Brewer and J.M. Plumb (eds). The Birth of a Consumer Society: The Commercialization of Eighteenth-Century England. Bloomington: Indiana.

- McRobbie, A., (1999). Postmodernizm ve Popüler Kültür. A. Özbek (trans). İstanbul: Gündüz Basım Yayın Dağıtım.

- Ritzer, G. and Goodman, D., (2006). 'Postmodern Social Theory' in J.H. Turner (ed). Handbook of Sociological Theory. New York: Springer Science+Business Media.

- Sassatelli, R., (2007). Consumer Culture: History, Theory and Politics. Wiltshire, Great Britain: The Cromwell Press.

- Scott, J. and Marshall, G., (2009). A Dictionary of Sociology. Third Ed. Revised. New York: Oxford University Press.

- Taşyürek, N., (2010). Reklam ve Reklamın Tüketicilerin Satın Alma Davranı̧̧ları Üzerindeki Etkisi: Bir Alan Araştırması. (Master's Thesis). Atılım Üniversitesi Sosyal Bilimler Enstitüsü, Ankara.

- Topçuoğlu, N.N., (1996). Basında Reklam ve Tüketim Olgusu. Ankara: Vadi Yayınları.

- Veblen, T., (2014). Aylak Sınıfın Teorisi. E. Günsel (trans). Ankara: Tutku Yayınevi.

- Zorlu, A., (2006a). Üretim ve Tüketim Teorileri. Ankara: Glocal Yayıları.

- Zorlu, A., (2006b). Modern Tüketim Tarihiden Tüketim Araştırmalarına Tüketim Sosyolojisi. Ankara: Glocal Yayınları. 